\title{
1492: partos do fecundo oceano relatos históricos sobre o descobrimento da América em dois tempos (as Décadas de Anglería e de Herrera)*
}

\section{2: deliveries of the fecund ocean \\ historical accounts of the discovery of America in two times (the Decades of Anglería and Herrera)}

\author{
ANDERSON ROBERTI DOS REIS** \\ Departamento de História \\ Universidade Federal de Mato Grosso \\ Cuiabá (MT) \\ Brasil
}

LUIZ ESTEVAM DE OLIVEIRA FERNANDES***

Departamento de História

Universidade Federal de Ouro Preto

Mariana (MG)

Brasil

RESUMO O artigo busca analisar as concepções de tempo e de escrita da história em dois cronistas, Pedro Mártir de Anglería e Antonio de Herrera y Tordesillas, ambos narradores dos eventos de 1492 em forma de "Décadas". O primeiro escrevendo no calor dos acontecimentos, na virada do XV para o XVI, e o segundo, no início do século XVII. Para atingir tais objetivos, buscamos uma contextualização de suas produções e procuramos verificar como suas concepções de história e de narrativa ligavam-se a preceitos

\footnotetext{
Artigo recebido em: 02/11/2013. Aprovado em: 06/08/2014.

http://dx.doi.org/10.1590/S0104-87752014000300007

** Doutor em História Social pela Universidade de São Paulo (USP). Contato: dosreiss@gmail.com.

*** Doutor em História Cultural pela Universidade Estadual de Campinas (UNICAMP). Contato: leof79@gmail.com.
} 
políticos e providenciais. Além disso, realizamos uma discussão sobre o próprio conceito de crônica e seus modos de registrar a história espanhola como um fenômeno atlântico ao longo do século XVI, mostrando o modo pelo qual as fórmulas de Anglería e de Herrera relacionavam-se com a tradição e a modernidade.

\section{Palavras-chave crônica, Anglería, Herrera}

ABSTRACT This paper analyzes the conceptions of time and history writing in two chroniclers, Pedro Mártir de Anglería and Antonio de Herrera y Tordesillas, both narrators of the events of 1492 using the form of "Decades". The first of them wrote in the heat of the events, at the turn of the $15^{\text {th }}$ to the $16^{\text {th }}$ century, and the second in the early $17^{\text {th }}$ century. In order to achieve these goals, we seek a contextualization of their productions, and persecute how their conceptions of history and narrative were linked to political and providential precepts. In addition, we have conducted a discussion on the concept of chronicle and how this form of historiography recorded the Spanish history as an Atlantic phenomenon through the 16th century, showing how Anglería and Herrera formulas were related to tradition and modernity.

Keywords chronicle, Anglería, Herrera

\section{Introdução}

Quando Pedro Mártir de Anglería (1456-1526) chegou à Espanha, o que o movia de Roma, onde passara seus últimos dez anos, era a vontade de estar no centro daquilo que ele (e tantos outros contemporâneos) considerava ser o acontecimento mais importante de seu tempo: a derrota dos mouros e sua definitiva expulsão de terras cristãs europeias. A pujança espanhola em fins do século XV o arrebatou. Ele acabou por se tornar historiador, participar da corte dos Trastâmara e narrar outro evento singular, tão ou mais importante que a queda de Granada: a chegada de Colombo (1451-1506) às Índias. Em seu tempo, à exceção do próprio Almirante do Mar Oceano e de Américo Vespúcio, ninguém foi tão lido e traduzido quando se tratava das desventuras ibéricas em além-mar.

Um século depois, quando Antonio de Herrera y Tordesillas (1549-1625) escreveu suas monumentais Décadas, o quadro europeu havia se alterado. Os muçulmanos ainda incomodavam, desta feita com os avanços turcos sobre o Sacro Império e no Mediterrâneo. A glória da Batalha de Lepanto (1571) distava apenas 30 anos no tempo. A unidade da fé católica (se é que isso pudesse, de fato, existir) estava definitivamente rompida depois de décadas de guerras religiosas por todo o continente. Ainda assim, a Espanha de grandezas já prenunciadas nos tempos de Anglería tornara-se 
uma realidade: a América confirmara-se como Novo Mundo e estava sob seu mando, embora os custos de tal operação fossem tão altos quanto o absurdo lucro que os metais propiciavam. Toda uma burocracia havia sido montada pelos Habsburgo para administrar suas possessões marítimas. Herrera fazia parte dela.

Em comum, Anglería e Herrera escreveram sobre o ano de 1492 e sobre Colombo, como ponto chave na expansão imperial espanhola. Ambos valeram-se do formato de "décadas", fórmula consagrada desde o século V, quando os escritos de Tito Lívio (59 a.C.-17 d.C.) sobre a história romana foram assim divididos. Neste artigo, pensaremos como os dois cronistas, separados pelo século XVI, narraram os eventos referentes ao descobrimento da América, tentando entender, com isso, como as formas historiográficas se alteraram nos dois textos e quais significados foram atribuídos à primeira viagem colombina.

A ideia sugerida no título, a de que o ano de 1492 foi mais um "parto do fecundo oceano", deriva de um fragmento do início do capítulo I da sétima década de Anglería: "Quae noua praegnas Oceanus pepererit, breui de preteritis epilogo praeeunte, nunc percurramus". ${ }^{1}$ Para o cronista, todos os anos novas ilhas, nações e riquezas eram dadas a descobrir pelo pródigo oceano. De nossa parte, extrapolamos a metáfora e sugerimos, neste artigo, a escrita da "história" do descobrimento da América com base em fontes que atravessaram o Atlântico, já que os escritores aqui analisados nunca viajaram ao novo continente. O "fecundo" indica, ainda, especificamente para o caso de Anglería, os fundamentos do discurso do "maravilhoso", que fazem parte da argumentação de quem vive e é cônscio da situação que narra, ainda que não a experimente em primeira mão. Suas Décadas foram escritas na forma de cartas para informar nobres, monarcas e o papa sobre o que se passava no Atlântico, sempre baseado nos testemunhos daqueles que protagonizaram tais feitos. Esses testemunhos podiam ser escritos, mas também ouvidos, em conversas, uma vez que o próprio Anglería nos conta que Colombo, Sebastián Caboto (1484-1557), Juan de Ribera (secretário de Hernán Cortés [1485-1547]), Américo Vespúcio (1454-1512), entre muitos outros, frequentaram sua casa ou se encontraram com ele em ambiente cortesão, revelando-lhe pessoalmente o que viram e viveram. Já para o caso de Herrera, a noção de "fecundo" implica o número de fontes e informações acumuladas por quase um século - das quais ele dispunha ao iniciar sua crônica oficial.

1 "As novidades geradas pelo fecundo oceano, precedido por um breve epílogo acerca das coisas do passado, agora percorramos". ANGLERÍA, Pedro Mártir de. De orbe nouo Petri Martyris ab Angleria Mediolanensis protonotarij C[a]esaris senatoris decades. Compluti: Apud Michaele[m] d[e] Eguia, 1530, f. xci. Embora tenhamos usado o original da obra em latim, optamos por grafar o nome de Anglería do modo mais utilizado pela historiografia de língua espanhola: Pedro Mártir de Anglería. Agradecemos a Luciano César Garcia Pinto pela ajuda com a tradução dos trechos em latim. 
1492 acabou se tornando um ano emblemático: o "ano admirável", cravou Bernard Vincent; o "ano decisivo", avaliou o romancista Carlos Fuentes. ${ }^{2}$ Eventos "admiráveis e decisivos" ocorreram na Península Ibérica então: a expulsão dos judeus, a dos mouros, a publicação da gramática de Antonio de Nebrija (1441-1522), a primeira de uma língua moderna europeia, e a descoberta da América. Mas essa consciência de que o ano era singular teria se produzido na própria época? ${ }^{3}$ Esse é um longo debate, cujas questões mais amplas devemos sintetizar a fim de nos situar.

Em 1995, Karen Kupperman organizou um livro que buscava justamente examinar qual impacto a América teria causado na consciência europeia. $\mathrm{Na}$ introdução, a historiadora norte-americana sublinha que não há consenso sobre o assunto:

Historiadores, olhando as consequências das viagens colombinas desde um vantajoso ponto de quinhentos anos de experiência, não concordam sobre o quanto a América impactou a compreensão europeia do mundo e de sua história, tampouco concordam sobre como caracterizar essa confrontação. ${ }^{4}$

O renomado historiador John H. Elliott, por exemplo, escreveu sobre as formas utilizadas pelos europeus em seus relatos sobre as terras ultramarinas de modo a enquadrá-las em modelos pré-determinados de narrativa e concepção de mundo, "forçando o estranho a se tornar familiar". Para o autor, a América teve um "impacto embotado" sobre a Europa. ${ }^{5}$ Por outro lado, há aqueles que, recentemente, advogaram o oposto: que as maneiras de narrar e pensar o mundo, pós-1492, "racharam", segundo sugeriu, por exemplo, Stephen Greenblatt, para quem, desde as primeiras explorações, houve literalmente uma "brecha, essa rachadura da compreensão contextual numa elusiva e ambígua experiência do maravilhamento". ${ }^{6}$ Anthony Grafton, por sua vez, escreveu acerca do modo pelo qual muitos humanistas, entusiasticamente, absorveram enormes quantidades de conhecimentos

2 VINCENT, Bernard. 1492: o ano admirável. Lisboa: Livros do Brasil, 1992; FUENTES, Carlos. O espelho enterrado: reflexões sobre a Espanha e o Novo Mundo. Rio de Janeiro: Rocco, 2001, p.79.

3 Apenas a título de comentário, a consciência do papel espanhol como protagonista do que parecia ser o maior acontecimento de todos os tempos aparece em outros cronistas e relatos da época, conforme se observa em López de Gómara: "La mayor cosa después de la creación del mundo, sacando la encarnación y muerte del que lo crió, es el descubrimiento de Indias; y así las llaman Nuevo Mundo". LÓPEZ DE GÓMARA, Francisco. Historia general de las Indias. Caracas: Biblioteca Ayacucho, 1978, p.7.

4 'Historians looking at the consequences of the Columbian voyages from the vantage point of five hundred years' experience do not agree on how much impact America made on European understanding of the world and its history, nor do they agree on how to characterize the confrontation"; KUPPERMAN, Karen (org.). America in european consciousness, 1493-1750. North Carolina: The University of North Carolina Press, 1995, p.2.

5 ELLIOTT, John. Renaissance Europe and America: a blunted impact? In: CHIAPPELLI, Fredi (ed.). First images of America: the impact of the New World on the Old. v.1, Berkeley: Berkeley University Press, 1976, p.11-23. Visões mais radicais, que mostram como grupos inteiros simplesmente ignoraram a experiência americana em favor da tradição, dos argumentos de origem clássica ou medieval, podem ser lidas em trabalhos como os de BORJA GÓMEZ, Jaime H. Los indios medievales de Fray Pedro de Aguado: construcción del idólatra y escritura de la historia en una crónica del siglo XVI. Bogotá: CEJA, 2002.

6 GREENBLATT, Stephen. Possessões maravilhosas: o deslumbramento do Novo Mundo. São Paulo: Edusp, 1996, p.36. 
advindos do Novo Mundo, conquanto os incorporassem a velhos esquemas interpretativos. ${ }^{7}$ Germán Arciniegas, de forma radical, afirmou que foi "com a América que o mundo moderno começou. Começa o progresso científico, se agiganta. Através da América, a Europa adquire uma nova dimensão e merge das suas sombras". ${ }^{8}$

O que estamos alegando neste artigo é que 1492 teve um impacto que poderia ser situado em algum lugar entre os dois polos paradigmáticos mencionados pela historiografia. Ou seja, por mais que pareçam excludentes, as duas posições sobre a emergência da América na consciência histórica europeia e em suas formas de narrativa e exposição fornecem contornos apenas parciais acerca do problema. Na verdade, defendemos que a consciência europeia, pós-1492, foi afetada de diferentes maneiras e em múltiplas camadas. E há pelo menos três considerações a se fazer a esse respeito.

A primeira delas é temporal. Peter Burke, analisando verbetes de dicionários, histórias naturais e outras publicações científicas da Europa pós-1492, percebeu que a América não se tornou, de fato, um marco narrativo até o século XVIII. Antes dessa data, o autor afirma que a "A América parece ter ocupado apenas um lugar menor na consciência histórica europeia". ${ }^{9}$ A virada pode ser apreendida por meio dos verbetes sobre a América, sua história natural e moral, que explodem em número de publicações depois de 1750.

A segunda é de caráter nacional e de filiação religiosa. Os ibéricos, donos dos maiores impérios americanos, publicaram muito a esse respeito. Tivessem eles maior influxo no restante da Europa, e essa literatura teria gerado mais impacto do que sugeriu Burke. Na Península Itálica, houve resposta imediata sobre a novidade das descobertas ultramarinas, com textos de Paolo Giovio (1483-1552), Francesco Guicciardini (1483-1540), Giovanni Battista Ramusio (1485-1557) e tantos outros. Mas isso parece coincidir com o período de associação entre as terras descoberta por Colombo e Vespúcio e as "Índias Orientais". Ao longo do XVI, fora da Península, o interesse pelo advento da América como marco da modernidade diminuiu. E o inverso se passou com a Holanda, onde os textos de Marcus Boxhorn (1612-1653), Hugo Grotius (1583-1645) e Joannes de Laet (1581-1649), por exemplo, estão na ponta de uma longa lista de autores que pareceram colocar os

7 "Tradition and innovation, modernity and reverence for the antique seemed compatible", afirmou GRAFTON, Anthony. New worlds, ancient texts: the power of tradition and the shock of Discovery. Cambridge: Cambridge University Press, 1992, p.116.

8 "with America, that the modern world begins. Scientific progress begins, philosophy thrives. By means of America Europe acquires a new dimension and emerges from its shadows"; ARCINIEGAS, Germán. America in Europe: a history of the New World in reverse. New York: Harcourt, Brace, Jovanovich, 1986, p.2.

9 "America seems to have had only a minor place in European historical consciousness"; BURKE, Peter. America and the rewriting of world history. In: KUPPERMAN, Karen (org.). America in European Consciousness, p.37. 
eventos pós-1492 no pináculo da existência humana. ${ }^{10}$ França e Inglaterra seguiram caminhos similares, menosprezando os feitos espanhóis, mas cobiçando as terras e metais americanos.

A terceira das considerações refere-se à reverência dos autores modernos em relação às formas de conhecimento e narrativa antigas. Sua manutenção como baliza dos textos sobre o Novo Mundo "podem ter servido como um obstáculo, mas também serviu como caminhos e técnicas para se compreender o novo". ${ }^{11}$ Some-se isso à visão providencialista associada ao discurso histórico em fins do século XV e ao longo do XVI, e se chegará à razão que nos levou a escolher os dois cronistas oficiais da Espanha: Anglería e Herrera. Analisaremos seus relatos sob esses parâmetros a fim de examinar a escrita da história em dois tempos: no calor dos acontecimentos, acompanhando Anglería, e no auge do século de ouro espanhol, seguindo a pena de Herrera.

\section{Formas da escrita}

Inspirados pela tradição filosófica clássica de buscar o meio-termo, quase sempre morada do justo, colocamo-nos então na seguinte posição: a emergência da América como quarta parte do mundo não se reduziu plenamente aos esquemas antes conhecidos, nem tampouco fez desmoronar completamente as bases do saber e das formas de narrar a história. Para que não haja equívocos em relação a esta afirmação é necessário reter os sentidos sugeridos pelos advérbios. Isto é, os vários relatos conhecidos acerca dos descobrimentos ibéricos e dos processos de colonização do continente americano sugerem diferentes escalas de apreensão da "nova realidade". Dos diários de Cristóvão Colombo, de cuja imaginação e abstração nasceram os índios, passando pela entusiasmada defesa dos nativos feita pelo dominicano Bartolomé de Las Casas (1484-1566) em meados dos Quinhentos, até chegar, já no terço final do século XVI, ao texto eivado de "notas empíricas" do padre jesuíta José Acosta, observam-se variações que exigem cautela daqueles que pretendem propor uma leitura de conjunto de obras tão diferentes na forma. ${ }^{12}$ Tal afirmação não se fundamenta na premissa de que podemos medir a apreensão de cada "viajante" porque conhecemos a realidade percebida. Ela se assenta, de outro modo, na

10 BURKE, Peter. America and the rewriting of world history, p.45.

11 "may have operated as an obstacle, but it also offered pathways and techniques for understanding the new"; KUPPERMAN, Karen (org.). America in European Consciousness, p.2-3.

12 A esse respeito, ver, por exemplo: BRUIT, Hector H. Bartolomé de Las Casas e a simulação dos vencidos. São Paulo: Iluminuras, 1995; FREITAS NETO, José Alves de. Bartolomé de Las Casas: a narrativa trágica, o amor cristão e a memória americana. São Paulo: Annablume, 2003; GREENBLATT, Stephen. Possessões maravilhosas; O'GORMAN, Edmundo. A invenção da América. São Paulo: Ed. Unesp, 1992; RABASA, José. Inventing America: spanish historiography and the formation of Eurocentrism. Oklahoma: University of Oklahoma Press, 1993; TODOROV, Tzvetan. A conquista da América: a questão do outro. São Paulo: Martins Fontes, 2003. 
hipótese de que as diferentes soluções narrativas encontradas por cada "observador" evidenciam, fornecem indícios sobre o impacto da novidade americana na percepção europeia. Talvez os exemplos mais eloquentes a esse respeito, tomados em comparação, sejam os relatos deixados por Colombo e por aquele que se tornou seu concorrente na fortuna do batismo do Novo Mundo, Américo Vespúcio.

A dispersão dos saberes sobre a América se deu por meio de narrativas as mais variadas. Há um "imenso movimento de textos e de homens" que não se limitou às rotas que ligavam a Europa ao Novo Mundo: tratava-se de idas e vindas planetárias que incluíram também a Ásia e a África. ${ }^{13}$ Os homens que se aventuraram em tais percursos registraram suas experiências - aqui tratadas como vivências - de modos bastante distintos e quase sempre correspondentes a seu lugar de fala. ${ }^{14} \mathrm{O}$ mais curioso, veremos adiante, é que até mesmo homens que nunca saíram de seus gabinetes para singrar o Atlântico se puseram a escrever a história americana. Diários, histórias (naturais, morais, sumárias, apologéticas etc.), anais, relaciones, crônicas, descrições, cartas, décadas. As formas de escrita eram tão diferentes quanto os lugares sociais ocupados pelos milhares de homens que as mobilizaram ao escrever: almirantes, cartógrafos, soldados, religiosos, burocratas, cosmógrafos, humanistas, cronistas oficiais, indígenas, mestiços. Já se sugeriu que esse mosaico de formas, para o caso hispano-americano, possa ser agrupado sob o nome genérico de "crônicas". ${ }^{15}$

O volume de informações nesses relatos é imenso e riquíssimo, o que levou alguns estudiosos, inclusive historiadores profissionais sérios, ${ }^{16} \mathrm{a}$ equiparar tais documentos a fontes etnológicas ou antropológicas avant la lettre. Por mais tentadora que possa parecer, essa atitude sugere certa transparência dos relatos e, por conseguinte, esvazia uma consideração teórica que para nós é fundamental e fundadora de nossa atividade intelectual: toda escrita decorre de uma prática histórica. ${ }^{17}$ Partilhar a premissa da alegada transparência significaria ignorar o fato de que cada um desses relatos foi construído,

em função de situações singulares que motivaram suas escritas. A relação de uma viagem ou de uma estadia longínqua funciona sempre como uma moeda com a qual se busca comprar notoriedade, reconhecimento, privilégios ou, às

13 LABORIE, Jean-Claude. A dispersão do saber missionário sobre as Américas de 1549 a 1610: o exemplo jesuíta. Revista de História, São Paulo, n. 52, p.9-27, 2005.

14 CERTEAU, Michel de. A escrita da história. Rio de Janeiro: Forense Universitária, 2002, p.65 e ss.

15 FERNANDES, Luiz Estevam O.; REIS, Anderson R. dos. A crônica colonial como gênero de documento histórico. Revista Ideias, Campinas, ano 13, n.2, p.25-41, 2006. Sobre o debate em torno da definição de crônicas e de sua tipologia na Espanha e nas Índias, ver: LIMA, Luiz Costa. Trilogia do controle. Rio de Janeiro: Topbooks, 2007, p.233-272; GONZÁLEZ BOIXO, José Carlos. Hacia una definición de las crónicas de Indias. Anales de Literatura Hispanoamericana, n.28, p.227-237, 1999.

16 Conferir: BRUIT, Hector H. Apresentação geral das crônicas. Revista Ideias, Campinas, ano 11, n. 1, p. 15-20, 2004

17 CERTEAU, Michel de. A escrita da história, p.65 e ss. 
vezes simplesmente, a vida. Não é apenas o contexto histórico da redação que importa, mas a situação de enunciação na medida em que o vínculo suscitado com o destinatário funda a estratégia da escrita. ${ }^{18}$

Partindo dessa observação de Jean-Claude Laborie, talvez possamos sugerir que o meio-termo, aquele a que temos almejado, nesse caso se encontre na seguinte formulação: o suposto valor historiográfico ou etnográfico de uma crônica ou relação de viagem deve estar condicionado a um lugar. Isto é: embora as crônicas não nos forneçam, através de uma transparência, a realidade dos processos históricos ou das vivências dos povos que habitavam a América no momento da descoberta e nas décadas subsequentes, elas nos dizem algo. Se não são transparentes, os relatos também não erguem muros intransponíveis entre nós e os outros, anulando quaisquer possibilidades de alteridade histórica. Propomos, para tentar reconciliar os dois polos, uma imagem semelhante a uma metáfora já empregada para explicar esse estatuto do documento: ${ }^{19}$ a de que as crônicas funcionam à maneira de um vidro jateado. Se esse tipo de vidro não permite a plena observação do outro lado, sem distorções, ele também não impede que vislumbremos os contornos, os traços e movimentos das coisas e pessoas contempladas através dele, de sua opacidade. Analisar a trama formada pelo jateamento, que conformará a "distorção", equivale em linguagem historiográfica a pensar a escrita como prática histórica, constituindo sob nossa perspectiva os limites e possibilidades de uso das crônicas e das fontes, de modo geral, pelos historiadores. De novo é Michel de Certeau, fazendo a hermenêutica do relato do calvinista Jean de Léry (1536-1613) sobre os Tupinambá no século XVI, quem sintetiza bem essa circunstância:

As experiências novas de uma sociedade não desvelam sua "verdade" através de uma transparência destes textos: são aí transformadas segundo as leis de uma representação científica própria da época. Desta maneira os textos revelam uma "ciência dos sonhos"; formam "discursos sobre o outro", a propósito dos quais se pode perguntar o que se conta aí, nesta região literária sempre decalada com relação ao que se produz de diferente. ${ }^{20}$

As crônicas podem ser ou não enquadradas no gênero "relato de viagem", dependendo da circunstância que originou cada uma delas, mas tampouco se reduzem a ele. Isso ocorre pelo simples fato de que há crônicas que não foram produzidas durante uma viagem ou por alguém que de fato viajou, o que elimina um aspecto central das narrativas de viagem: a marca do "eu vi". Ao analisar os relatos do Léry, Certeau já havia chamado

18 LABORIE, Jean-Claude. A dispersão do saber missionário sobre as Américas de 1549 a 1610, p.10-11.

19 KARNAL, Leandro. Os textos de fundação da América: a memória da crônica e a alteridade. Revista Ideias, Campinas, ano 11, n.1, p.9-14, 2004.

20 CERTEAU, Michel de. A escrita da história, p.213. 
a atenção para esse detalhe, sublinhando a capacidade que a escrita fixar, tornando não perecível, o que tinha sido visto, bem como aquilo que se sabia ou ouvia por meio de rituais nativos. Captar as palavras ditas e inscrevê-las em um texto era uma forma de escrever uma relação com outro. Contudo, foi François Hartog, ${ }^{21}$ também ele tomando os relatos de Jean de Léry como horizonte de comparação pontual para seu objeto de análise, as Histórias de Heródoto, quem enfatizou o aspecto central que atravessa as narrativas de viagem: a tradução.

O argumento d'O Espelho de Heródoto pode ser sintetizado da seguinte maneira: toda narrativa de viagem pressupõe uma operação básica: traduzir o mundo que se conta para o mundo em que se conta. Para tanto, há alguns procedimentos - verificáveis nesse gênero literário - que se encarregam de cumprir tal função (inversão, comparação, analogia etc.), criando uma "retórica da alteridade". ${ }^{22}$ Entre estes procedimentos situa-se o recurso do "eu vi" como marca de enunciação, que acaba por distinguir o relato de viagem (os diários de Colombo, por exemplo, nos quais esse recurso foi possível) de uma crônica escrita desde a Europa sobre a descoberta da América (as Décadas de Anglería, por exemplo, nas quais predomina a noção do "eu soube" e "eu ouvi dizer"). ${ }^{23}$ De todo modo, tanto a crônica - preocupada com o registro temporal e às vezes impedida de recorrer ao "eu vi" - como os relatos de viagem caracterizados por essa "marca do olhar" supõem um narrador a contar para um público-alvo imaginado (já que o alcance da dispersão e as medidas da recepção não podem ser conhecidos) algo sobre um terceiro, no nosso caso, a América. Logo, pulsa em ambos os tipos de documento histórico a necessidade de traduzir.

Os artifícios usados para traduzir o mundo que se conta podem nos informar algo, para retomarmos a metáfora, sobre o nível de distorção do jateado que foi aplicado ao vidro. A translucidez, nesse caso, tem duplo valor: ela nos permite visualizar a relação estabelecida entre os dois mundos (o que se conta e aquele em que se conta), ao mesmo tempo em que nos ajuda a compreender o impacto do novo continente na consciência europeia - e, portanto, na relação que aqueles narradores estabelecem com a

21 HARTOG, François. O espelho de Heródoto: ensaio sobre a representação do outro. Belo Horizonte: Ed. UFMG, 1999.

22 HARTOG, François. O espelho de Heródoto, p.227 e ss.

23 Para um ensaio sobre a historiografia e os relatos de viagem, partindo dos textos de Jean de Léry e André Thevet, que fornece uma boa visão sobre o estado da arte da produção historiográfica francesa sobre o tema, ver: CEZAR, Temístocles. Thevet e Léry: visão, crença e história no Brasil do século XVI. Ensaio sobre historiografia e relatos de viagem. Ciências \& Letras, n.37, p.27-43, 2005. Para um debate teórico a respeito de tal gênero documental, conferir: JESÚS BENITES, María. Los derroteros teóricos de una categoría heterogénea: los relatos de viajes al Nuevo Mundo (Siglo XVI). Moderna spräk, v.107, n.1, p.31-38, 2013. Para uma análise dos relatos dos viajantes e sua literatura na América portuguesa do século XVI, ver também: LEITE, José Roberto T. Viajantes do imaginário: a América vista da Europa, séc. XV-XVII. Revista da USP, São Paulo, n.30, p.33-45, 1996; PERRONE-MOISÉS, Leyla. Alegres trópicos: Gonneville, Thevet e Léry. Revista da USP, São Paulo, n.30, p.85-93, 1996; THEODORO, Janice. Visões e descrições da América: Alvar Nunez Cabeça de Vaca (XVI) e Hercules Florence (XIX). Revista da USP, São Paulo, n.30, p.75-83, 1996 
tradição (e com os Antigos) e com o tempo. Os mecanismos de tradução e sua disposição em uma narrativa, nessa proposta, constituiriam uma interessante régua para avaliar a apreensão da realidade e sua plausibilidade. Tomemos um exemplo comparativo para ilustrar o caso.

Cristóvão Colombo, desejando convencer seu público, os reis católicos, descreve em seus Diários vários elementos da natureza das terras encontradas, valendo-se de suas expectativas e da comparação com um modelo conhecido/imaginado. Dessa distorção e da inconsciência de que se descobriram novas terras, produzem-se vários equívocos como a noção de índio ou a ideia de que se chegaria ao paraíso conforme as expedições avançassem rumo ao sul do continente. Nesse sentido, a tradução efetuada por Colombo está de tal maneira atrelada a sua visão de mundo, e a figuras que remetem a modelos estabelecidos pela tradição, que o impacto da novidade americana se evanesce, obscurecido pelo fato de Colombo sequer ser capaz de compreender ter chegado a outro lugar que não as Índias.

Por outro lado, Hernán Cortés, duas décadas mais tarde, cônscio de estar em "terra firme" de um Novo Mundo, ignorado pelos Antigos, descreve em suas Cartas de Relação os templos mexicas e, para traduzi-los para a outra margem do Atlântico, compara-os a mesquitas muçulmanas. Com efeito, o procedimento da comparação não permite ao público-alvo do conquistador espanhol saber como eram de fato aqueles templos, do mesmo modo que não nos oferecem, a nós historiadores modernos, a chance de sabê-lo. Porém, a comparação em Cortés não elimina completamente o elemento americano, mas estabelece outra gradação de tradução do outro, neste ponto mais plausível a nossa percepção. Se à consciência europeia do século XVI não era possível conhecer as fabulosas pirâmides de México-Tenochtitlán, era-lhe factível ao menos reconhecê-las através dos diáfanos contornos oferecidos pelo relato/vidro anteposto por Cortés, cujo jateamento consistia em uma tradução fundamentada na relação "antiga" entre cristãos e islâmicos.

Em um caso, o de Colombo, a escrita da experiência americana dissolvia a novidade em uma forma pronta e acabada - ancorando o presente do relato em um passado, modelar e compartilhado, potente o suficiente para amortecer a vivência e o estranhamento. No outro caso, o de Cortés, a escrita da experiência conquistadora acomodava a novidade em uma estrutura conhecida, sem, contudo, eliminá-la completamente da narrativa, estabelecendo uma relação temporal mais fluida: o relato remetia a um passado, modelar e compartilhado, que retornava para o presente para se conectar com o universo de significação (os conflitos entre cristãos e mouros) do narrador e de seu público-alvo. 
Michel de Montaigne (1533-1592), em seus Ensaios ${ }^{24}$ publicados no terço final do século XVI, já havia ao menos intuído o impacto da irrupção do indígena, um "outro", em seu mundo. Aliás, do indígena e do significado do aparecimento da América cerca de um século antes. Entre os historiadores contemporâneos, talvez tenha sido François Hartog aquele a sublinhar esse aspecto de modo mais sistemático. Desde a publicação de sua tese doutoral em 1980, O Espelho de Heródoto, ele tem examinado a dimensão do tempo, da alteridade e da relação entre Antigos e Modernos - chamando atenção, especificamente em Anciens, modernes et sauvages, ${ }^{25}$ para o fato de os "selvagens" do Novo Mundo, à semelhança de um estranho incômodo, terem recolocado o problema da relação entre Antigos e Modernos. ${ }^{26}$

O surgimento dos nativos entrava, então, em disputa. Ao mesmo tempo em que os modelos antigos de explicação do mundo se rejuvenesciam sob a alegação de que tal novidade estava prevista pelo conjunto de referências procedente dos autores clássicos, os "homens modernos" construíam outra interpretação. Temístocles Cezar, valendo-se do diálogo com Hartog, sintetizou bem este posicionamento: "caracterizado por semelhanças ou afastamentos, o paralelo entre Antigos e selvagens adquire a condição de instrumento heurístico, sobretudo para os Modernos, cujo efeito é a ideia nova e importante de que existe uma analogia entre o afastamento no espaço e no tempo" ${ }^{27}$ Isto é: entre Modernos e Antigos - estes aproximados estrategicamente dos selvagens - interpõem-se não apenas a dimensão temporal, séculos de distância, mas a espacial, a vastidão do oceano Atlântico.

As crônicas sobre a descoberta da América, conforme argumentamos, são escritas e inscritas nesse debate, e cada uma, a sua maneira, constrói uma experiência de tempo. Pois é exatamente esse o fundamento da formulação e do uso do conceito modernus: a percepção temporal. É razoável supor, hipoteticamente, que a temporalidade estruturadora do relato de um soldado que participara da conquista do México, como Hernán Cortés ou Bernal Díaz de Castillo (1496?-1584), seja diferente daquela que organiza a narrativa de um missionário franciscano, como frei Gerónimo de Mendieta [1525-1604] (escrevendo na virada do século XVI para o XVII) - conquanto

24 MONTAIGNE, Michel de. Os ensaios: uma seleção. São Paulo: Companhia das Letras, 2010, p.466 e ss.

25 HARTOG, François. Anciens, modernes, sauvages. Paris: Galaade, 2005.

26 Não é o caso, aqui, de refazer o percurso historiográfico de François Hartog sobre o tema. Para leituras pontuais da obra desse historiador a respeito das questões que estamos tratando neste texto, ver: HARTOG, François. Os antigos, o passado e o presente. Brasília: Ed. UnB, 2003, p.97 e ss.; HARTOG, François. Tempo, história e escrita da história: a ordem do tempo. Revista de História, São Paulo, v.148, n.1, p.9-34, 2003; HARTOG, François. Le classique, le moderne et nous. Revista de História, São Paulo, edição especial, p.21-38, 2010; HARTOG, François. Evidência da história: o que os historiadores veem. Belo Horizonte: Autêntica, 2011, p.45-142, p.253-264; HARTOG, François. Regimes de historicidade: presentismo e experiência do tempo. Belo Horizonte: Autêntica, 2013, p.93132; p.193-246.

27 CEZAR, Temístocles. Antigos, modernos e "selvagens" na obra de Francisco Adolfo de Varnhagen: comparação e paralelo na escrita da história brasileira oitocentista. In: PIRES, Francisco Murari (org.). Antigos e modernos: diálogos sobre a (escrita da) história. São Paulo: Alameda, 2009, p.169-186, p.173. 
ambas abordem temas semelhantes. Com efeito, a compreensão das maneiras pelas quais o Novo Mundo impactou a consciência europeia exige a análise da articulação dos tempos na escrita da e sobre a América nesses documentos. Para tanto, como não poderia deixar de ser - e segundo temos insistido - confluem duas dimensões analíticas: a do conteúdo e a da forma. A propósito desta, são necessárias duas ou três palavras sobre os textos de Pedro Mártir de Anglería e de Antonio de Herrera, que ora nos interessam.

A escrita da América, vimos anteriormente, acomodou-se em formas variadas: das descripciones às histórias, das cartas às crônicas, das relaciones aos anales. O leque era amplo, e escolher um ou outro modelo constituía um ato eloquente. Nesse sentido, a opção de nossos autores é no mínimo curiosa: diante de diferentes possibilidades, Anglería e Herrera, separados por um século, optaram por redigir suas histórias em forma de Décadas, solução conhecida nos Quinhentos, cujo modelo, contudo, foi pouco adotado pelos cronistas do Novo Mundo. Em suma, tratava-se de dividir o relato em dez livros ou capítulos que, subdivididos ainda mais em seu interior, abarcavam um recorte esticado em um arco temporal que variava de uma obra para outra.

É possível que o principal modelo a orientar essa escolha tenha sido Tito Lívio e sua História de Roma (Ab Urbe Condita) ${ }^{28}$ escrita no século I a.C., que, embora não tivesse sido originalmente concebida e dividida dessa maneira, ficou assim conhecida ao longo da Idade Média e em suas primeiras edições modernas. ${ }^{29}$ Juntamente com Virgílio (70 a.C.-19 a.C.), no campo da poesia, e Cícero (106 a.C.-43 a.C.), no âmbito da retórica, Tito Lívio era uma das principais referências da tradição latina para os autores humanistas - e, segundo Gabriella Albanese, provia "o modelo absoluto de escrita para a história" ${ }^{30}$ Basta trazer à memória, como exemplo, a incursão de Nicolau Maquiavel (1469-1527) na "primeira década de Tito Lívio" a fim de extrair dali elementos que pudessem orientar sua reflexão sobre a história e a política italianas.

Anglería não escondia o entusiasmo com a obra daquele autor romano ao afirmar, no capítulo 9 da primeira década de seu relato, que gostaria de

28 TITO LíviO. Todas las decadas de Tito Livio. Madrid: Casa Arnaldo Byrcman, 1554.

29 SYME, Ronald. Livy and Augustus. Harvard Studies in classical philology, v.64, p.27-87, 1950. Especialmente o trecho à página 30: "A division of the work in decades is attested in late antiquity by the letter of Pope Gelasius". Há um longo debate a respeito da organização original da obra de Lívio, cuja provável estrutura teria sido arranjada em torno de pêntades (cinco livros) e décadas (dez livros), cada uma dessas unidades constituindo uma espécie de grupo geralmente antecedido por um prefácio. Considerando-se a pequena porção conhecida da obra liviana (35 ou 36 livros do total de 142), é possível ter uma dimensão das dificuldades de estabelecer com precisão o edifício do livro. Para um excelente apanhado desses debates, bem como para a fortuna crítica da $A b$ urbe condita, ver: COLLARES, Marco Antonio. Representações do senado romano na Ab urbe Condita Libri de Tito Lívio: livros 21-30. São Paulo: Cultura Acadêmica, 2010, p.77 e ss. Os autores agradecem a Fábio Joly pelas valiosas indicações bibliográficas nesse sentido.

30 ALBANESE, Gabriella. A redescoberta dos historiadores antigos no Humanismo e o nascimento da historiografia moderna. In: PIRES, Francisco Murari (org.). Antigos e modernos, p.277-330, p.278. É verdade, também, que outros autores clássicos foram incorporados ao repertório humanista de leituras, a exemplo do "patrimônio literário grego" e de escritores latinos do porte de Júlio César, Salústio, Tácito, Suetônio, entre outros. 
ter recebido o espírito de Lívio para poder escrever melhor a década cuja redação acabara de finalizar. Se não fez uma reverência explícita em suas Décadas de Índias, título pelo qual ficou conhecida sua Historia General de los hechos de los Castellanos en las Islas y Tierra-Firme de el Mar Oceano, Herrera prestou homenagem a Tito Lívio em outro livro, os Discursos Morales, Políticos e Históricos, publicado apenas em 1804. Ali, o cronista espanhol referia-se a Lívio, em meio a um apanhado de grandes escritores grecolatinos, como "el primero de los mejores historiadores". ${ }^{31}$

O recurso ao formato das Décadas, se não transportou diretamente o espírito de Tito Lívio da Roma Antiga para a Espanha do Renascimento como desejara Anglería, pode nos fornecer pistas, embora difusas, sobre a concepção de história (e, pois, de tempo) que fundamenta o relato de ambos e sobre o tamanho do tributo prestado por eles às referências antigas. De modo geral, inspirar-se em Tito Lívio indicava algumas possibilidades de escrita da história. Em primeiro lugar, significava a adoção de uma perspectiva temporal vinculada a historia magistra vitae, ${ }^{32}$ modelo consagrado por Cícero e seguido por outros historiadores romanos - incluindo Salústio (86 a.C.-34 a.C.), o próprio Tito Lívio e Tácito (55 d.C.-120 d.C.) - cujo "regime de historicidade" vigorou até o avançado do século XVIII. ${ }^{33}$ Escrevendo em meio à crise da República Romana, Tito Lívio compôs uma história comprometida com uma finalidade moral: investigar o passado romano a fim de encontrar as razões que fizeram definhar os costumes e a política. ${ }^{34} \mathrm{O}$ passado explicaria o presente: conhecer os exemplos pretéritos ajudaria a se guiar no mundo atual. Quando a tradição humanista revê o modelo dos exempla, a palavra-chave do novo esquema ganha contornos precisos: prudência. Aprofundar-se nas letras, nos studia humanitatis, a fim de conhecer o passado era um modo de se formar para agir no presente virtuosa e prudentemente. ${ }^{35}$

Para realizar tal investigação do passado, e esta é a segunda observação que gostaríamos de pontuar, Tito Lívio remonta às origens de Roma, "de longe a tentativa mais ambiciosa feita por qualquer historiador latino

31 HERRERA, Antonio de. Discursos morales, políticos e históricos ineditos de don Antonio de Herrera, cronista del Rey don Felipe Segundo, autor de las decadas de Indias, y de otras muchas obras. t.I, Madrid: Imprenta de Ruiz, 1804, p.30.

32 "Qualquer que seja o ensinamento que subjaz à nossa fórmula [historia magistra vitae], há algo que sua utilização indica de modo inegável. Seu uso remete a uma possibilidade ininterrupta de compreensão prévia das possibilidades humanas em um continuum histórico de validade geral. A história pode conduzir ao relativo aperfeiçoamento moral ou intelectual de seus contemporâneos e de seus pósteros, mas somente se e enquanto os pressupostos para tal forem basicamente os mesmos. Até o século XVIII, o emprego de nossa expressão permanece como indício inquestionável da constância da natureza humana, cujas histórias são instrumentos recorrentes apropriados para comprovar doutrinas morais, teológicas, jurídicas ou políticas". KOSELLECK, Reinhart. Futuro passado: contribuição à semântica dos tempos históricos. Rio de Janeiro: Contraponto/PUC-RJ, 2006, p 43.

33 KOSELLECKK, Reinhart. Futuro passado, p.43; HARTOG, François. Regimes de historicidade.

34 DOSSE, François. A história. Bauru: Edusc, 2003, p.106-108.

35 Conferir: HARTOG, François. A história de Homero a Santo Agostinho. Belo Horizonte: Ed. UFMG, 2001, p.189-221. 
até então". ${ }^{36}$ Ambiciosa porque, diferentemente de seus antecessores, Lívio começa sua narrativa pelas origens escrevendo sobre eventos que não presenciara, com fontes quase nunca originais, buscando menos 0 rigor da verdade do que exemplos úteis - em geral extraídos de autores mais antigos. Seu lugar da escrita não é o de continuador da narrativa de Salústio, ${ }^{37}$ mas daquele que deseja voltar a tempos remotos a fim de esticar o fio rubro da decadência moral que assolava os romanos. Ele é, portanto, um historiador de gabinete e biblioteca, ${ }^{38}$ e nesse sentido talvez possa ter servido de modelo historiográfico para nossos dois autores "modernos", que escreveram sobre coisas que não viram, a descoberta da América, mas das quais tiveram notícias.

Feitas essas observações, passemos às crônicas de nossos dois autores. A proposta é verificar, a partir de agora, como eles narraram o descobrimento da América e analisar semelhanças e diferenças entre Anglería e Herrera, sublinhando os modos de escrever a história da América e também do mundo moderno.

\section{Um italiano na corte Trastâmara: Anglería e o Orbe Novo}

Pedro Mártir de Anglería, embora o topônimo em seu nome queira apontar para outro lugar, nasceu em Arona, ao redor do ano 1456, ainda que sua família, de razoável nobreza, fosse originária de Anghiera, próxima de Milão. Protegido desde tenra idade por Juan Borromeo, conde de Arona, com quem manteve correspondência por toda a vida, dedicou-se ao estudo das "letras humanas". Destacando-se como escritor e humanista, foi levado a Roma, em 1471, onde conviveu na corte de homens poderosos.

Mudou-se para a Espanha em 1487 movido, já afirmamos, pelo desejo de participar da luta contra os muçulmanos que ali se desenrolava. Em Madri, foi recebido na corte real e de lá se dirigiu a Granada. Nunca tomou parte em batalhas propriamente, tendo se ocupado de narrar em cartas os sucessos da Reconquista. Ele próprio afirma que pensara em voltar à Itália, quando a "singular benignidade" dos reis católicos para consigo o reteve em terras ibéricas. Sentindo-se guiado pela Providência, tomou hábito sacerdotal e passou a ensinar latim e humanidades na corte real, como continuo. Uma década mais tarde, já capelão da rainha Isabel, foi designado maestro de los caballeros en artes liberales. Em 1501, exercendo a função de embaixador espanhol, foi enviado ao Egito e, a partir de 1520, integrou o Conselho Real de Castela (ocupando o cargo de Cronista Real de Castela) e a Junta de

\footnotetext{
36 MARQUES, Juliana Bastos. Tradição e renovações da identidade romana em Tito Lívio e Tácito. São Paulo: Universidade de São Paulo, 2007, p.7 (História, Tese de doutorado).

37 MARQUES, Juliana Bastos. Tradição e renovações, p.7.

38 DOSSE, François. A história, p.107.
} 
Índias. Quatro anos depois, tão logo se criou o Real e Supremo Conselho de Índias, fez parte de seus quadros.

Sobre as viagens de Colombo (e também sobre a de Pedro Alonso Niño e Cristóbal Guerra, entre 1499 e 1500), o primeiro escrito do humanista lombardo foi publicado em Veneza, em 1504, intitulado Libretto de tutta la nauigatione del Re de Spagna de le isole et terreni nouamente trouati. Era uma reunião de cartas de Anglería traduzidas, sem autorização de seu autor, ao dialeto vêneto pelo secretário do embaixador da República de Veneza na corte espanhola. Sete anos depois, vinha a lume a Mediolanensis opera. / Legado Babylonica. / Oceani Decas. / Poemata. / Epigrammata. / cum priuilegio, edição sevilhana editada por Jacobo Cromberger que reunia (o título mostra) várias obras de Anglería, incluindo os relatos de sua viagem ao país do Nilo e a primeira "década do oceano", acompanhada de um mapa do que se conhecia da América até então. ${ }^{39}$

Uma edição com três décadas foi publicada em 1516, com um imenso título aqui abreviado como De Orbe Nouo Decades, estampado, sob os auspícios de Antonio de Nebrija, por Arnaldo Guillermo de Brócar, em Alcalá de Henares. O próprio título da obra mostra uma mudança de consciência também presente no texto de Anglería. Ao passo em que a edição anterior referia-se a uma "década de oceano", esta mencionava um Orbe Novo, literalmente um Novo Globo. Ainda que a expressão Mundus Novus seja creditada a Américo Vespúcio, por conta de sua popular carta assim intitulada, escrita em 1503, Anglería já alegava tratar-se de uma novidade maior antes mesmo de o próprio Colombo ter tido tal ideia.

Em primeiro lugar, é preciso distinguir semanticamente Mundus e Orbus. O primeiro termo é usado por Vespúcio para se referir às novas terras descobertas, que não deveriam pertencer à Ásia, mas que formavam um novo continente, uma quarta parte do Mundo, até então desconhecida dos Antigos. Já Orbus, usado por Anglería, referia-se a todo o novo hemisfério que se descortinava, um planeta que dobrava de tamanho, incluindo terras e um vasto oceano - do qual os Antigos apenas conheciam uma parte.

Desde 1493, Pedro Mártir duvidara da interpretação colombina de que as descobertas do ano anterior diziam respeito às Índias. ${ }^{40}$ Pouco tempo

39 Nele, todo o mundo americano explorado oficialmente pela Espanha está descrito. Trata-se do mar do Caribe incluindo (ao centro) as ilhas de Hispaniola, Cuba e Jamaica, a costa da Flórida (à direita, ainda com o nome de "ilha" e com contornos indefinidos) e da América Central (à esquerda). (ver: John Carter Browm Map Collection. Disponível em: <http://jcb.lunaimaging.com/luna/servlet/detail/JCBMAPS 1 1 1177 10005 0007:0232> Acesso em: 27 set. 2013.

40 O próprio Colombo, à medida que continuava suas navegações, intui se tratar de um Novo Mundo, de fato, mas refuta sua intuição, optando pela tradição: como a Terra tinha de ser tripartite, o Almirante disse que a massa de terra que supunha estar na origem do rio Orinoco devia se tratar do paraíso terrestre, terra já conhecida, mas ainda não descoberta. Para uma discussão sobre a consciência de Colombo de sua descoberta, ver: GIUCCI, Guillermo. Viajantes do maravilhoso: o novo mundo. São Paulo: Companhia das Letras, 1992, p.100-149; GREENBLATT, Stephen. Possessões maravilhosas, capítulo 2; O'GORMAN, Edmundo. A invenção da América; RABASA, José. Inventing America; SMITH, Jonathan Z. Relating religion: essays in the study of religion. Chicago: University of Chicago Press, 2004, p.266-268. Ver, também, a interpretação do historiador português Vitorino M. Godinho, 
depois do retorno de Colombo à Espanha, Anglería escreveu cartas nas quais se referia às terras achadas pelo Almirante em sua primeira viagem como antipodibus occiduis (Antípoda ocidental), ${ }^{41}$ um novo terrarum hemisphaerio (hemisfério terrestre) ${ }^{42}$ e ao navegador como ille novi orbis repertor, descobridor de um novo globo. ${ }^{43}$ Todas essas referências seriam incorporadas à redação das Décadas, também escritas na forma de cartas, já no ano de 1494.

O historiador mexicano Edmundo O'Gorman advertia que a primeira década (concluída em 1501) ${ }^{44}$ mantém uma espécie de ceticismo fundado em seu humanismo e conhecimento científico da época. Para o autor, Anglería não estava alheio aos debates acerca do tamanho da esfera terrestre. ${ }^{45}$ Nas Décadas, ele primeiro busca mostrar que a opinião colombina poderia estar correta, resgatando Aristóteles e Sêneca como autoridades antigas que criam haver uma relativa proximidade entre a Ásia e a Europa. O segundo argumento era a presença de papagaios, "ave asiática", nas ilhas descobertas por Colombo. Por outro lado, Pedro Mártir descartou a hipótese de que Hispaniola fosse, como propôs o Almirante, a Ofir mencionada na Bíblia, à qual as naus do rei Salomão aportaram para se abastecer de ouro. Além disso, ele aventou que tais ilhas podiam ser, na verdade, um arquipélago intermediário entre a Ásia e a Europa, que desde o início do século XV aparecia em cartas náuticas, mapas-múndi e lendas ibéricas, associado por vezes às ilhas afortunadas (mencionadas por Plínio, o Velho [23-79], por exemplo): tratava-se das Antilhas, literalmente as ilhas que antecediam à chegada a Cipango e que a cartografia medieval localizava no Atlântico. Tais ilhas, acreditava-se, poderiam ser antipodais a Portugal, e é possível que isso tenha levado Anglería a referir-se ao descobrimento de "antípodas ocidentais", conforme notamos acima.

para quem o termo "descoberta" não só é pertinente para dar conta dos processos históricos ibéricos do final do século XV (ao contrário de "invenção da América"), mas sintetiza algo único: a invenção da humanidade. GODINHO, Vitorino Magalhães. Que significa descobrir? In: NOVAES, Adauto (org.). A descoberta do homem e do mundo. São Paulo: Companhia das Letras, 1998, p.55-82.

41 Carta de 14 de maio de 1493, extraída de: ANGLERÍA, Pedro Mártir de. Opus Epistolarum Petri Martyris Mediolanensis (...). Amstelod.: typis Elzevir; Paris: F. Leonard, 1670, p.89.

42 Carta de 13 de setembro de 1493, extraída de: ANGLERÍA, Pedro Mártir de. Opus Epistolarum, p.73.

43 Carta de 1 de novembro de 1493, extraída de: ANGLERÍA, Pedro Mártir de. Opus Epistolarum, p.76.

44 Nos anos posteriores, Anglería escreveu outras sete décadas. A oitava foi concluída no ano de sua morte, 1526, já cônscio dos feitos da expedição de Magalhães e a primeira volta ao mundo. Em 1530, em Alcalá, Miguel de Eguía foi o editor da primeira reunião das oito décadas sob o título De Orbe Nouo Petri Mártiris ad Angleria, Mediolanensis protonotarii, Cesaris Senatoris. Esta é a edição aqui utilizada. As traduções para o espanhol foram feitas, na íntegra, a partir do século XIX. A primeira, feita em 1892 pelo presbítero Joaquín Torres Asensio, ainda é a mais reeditada. Composta no contexto da celebração do IV Centenário do Descobrimento da América, tal tradução é marcada pelo nacionalismo espanhol finisecular e "su inusitado afán por recuperar, preservar y mostrar las fuentes documentales que consideraron testimonio de la grandeza de su pátria", conforme CASTILLA, Carlos Enrique. Encontrar o descubrir: en torno a la construcción de un campo semántico en las Décadas de Pedro Mártir de Anglería y su traducción de 1892. Diálogo de la Lengua, v.ll, p.98-111, 2010. Em 1964, Agustín Millares Carlo, paleógrafo e bibliógrafo espanhol, traduziu a edição de 1530 para o espanhol, e a publicou no México, pela Porrúa, com estudo preliminar de Edmundo O'Gorman. Em 2004, Stelio Cro, professor do King College, em Bristol, Tennessee, realizou nova tradução, publicada em Córdoba, Argentina, pela Editorial Alción.

45 O'GORMAN, Edmundo. A invenção da América, p.121-124. 
No horizonte de expectativas de Anglería, para recorrer à categoria proposta por Koselleck na obra já citada, o feito colombino era o pináculo dos tempos, algo inédito, imprevisto pelos Antigos, mas ainda insondado em sua amplitude naqueles tempos. O tempo futuro traria novidades ainda maiores e o conhecimento se ampliaria de um modo jamais vislumbrado pelos Antigos. Era possível para o cronista concordar com a visão de amazonas, sereias e harpias, debater teses sobre o descobrimento da bíblica Ofir e do paraíso terrestre, aventar a possiblidade tardo-medieval das Antilhas e acreditar que os índios viviam na Idade de Ouro, pois ele narrava no tempo em que se viviam tais diatribes. Esse "Novo Globo" descrito por um italiano na corte dos Trastâmara devia, por essa razão, reforçar moralmente a tese do Orbis terrarum e da Providência mostrando aos homens terras nunca antes vistas. Por estar no tempo e ser consciente de que quem narrasse depois dele poderia, por meio da experiência e da passagem do tempo, corrigir suas interpretações, escreveu um texto que podia conter elementos fabulosos e maravilhosos, antigos e modernos, mensuráveis por meio da experiência de nautas destros e, ao mesmo tempo, estar carregado de referências quase edênicas sobre seus habitantes (excetuando os estranhos canibais e seu horrendo hábito de comer carne humana).

Um exemplo disso está na Carta Proemial da primeira década, escrita para a edição de 1516 (e mantida nas demais edições desde então), que contém uma dedicatória da obra ao jovem Carlos V (1500-1558). Nela o lombardo escreveu:

Quod uniuersam tibi aui materni subdiderint Hipaniã angulo excepto: q pulchrã tibi, cû feracibus nostri maris insulis, Parthenopem, reliquerint, magnum quidem, \& ea nos per annales annotavimus, in quibus, per epistolaria epitomata, uiuentium omniû principum nostrae tempestatis universa gesta collegimus. Sed pace maior û dictum uelim, quicquid ab initio mundi gestû scriptûq; reperio, meo iudicio parû est, si pensitauerimus, quas tibi Rex potêtißime nouas terras, quae noua maria, quã uarias nationes \& línguas, ọles aurifodinas, quae margaritarû uiuaria (...) Veni ergo ueni, Rex electe, à superis ad nondû ab homnibus intellectû rerû aliquod culmê, ueni \& propera, aeqnoctialê tibi circulu latêsê hactenus, \& furentê atq; ardore solis adusta antiquorum opinione zonã, paucis exceptis, tibi paratã habem9, populis refertißimam, amoenam, uberem, fortunatißimã, auro \& candentibus mar garitis coronatas mille insulas, \& uno putato côtinêti três Europas offeremus, ueni nouû orbem, amplexurus (...) hinc tenelle Rex clarißime instrimenta quibus totus tibi pareat orbis, comparabuntur. ${ }^{46}$

$\mathrm{Na}$ citação vemos Anglería chamar o primeiro monarca Habsburgo à Espanha, de onde governaria os outros povos, uma vez que este vivia

46 ANGLERÍA, Pedro Mártir de. De orbe nouo Petri Martyris ab Angleria Mediolanensis protonotarij C[a]esaris senatoris decades. Compluti: Apud Michaele[m] d[e] Eguia, 1530, f. v. Na tradução para o espanhol de 1892: "El que vuestros abuelos maternos os hayan sometido toda la España, excepto un rincón; el que os hayan dejado la hermosa Nápoles con las fértiles islas de nuestro mar, cosa grande es ciertamente, y así lo he consignado yo 
momento inédito e superior aos demais ("à superis ad nondû ab homnibus intellectû rerû aliquod culmê"). Os descobrimentos tornavam singulares aqueles tempos, coisa que os Antigos não conheciam ("Sed pace maior û dictum uelim, ... quae margaritarû uiuaria").

Mas não nos enganemos com o vocábulo "descobrir" que temos usado em português moderno, nunca utilizado por Anglería. Discooperire, verbo latino que está na raíz de "descobrir", é uma forma tardia composta pelo prefixo dis ("sentido contrario") e pelo verbo coperire (ocultar, cobrir). Conforme bem apontou Carlos Enrique Castilla, em sentido literal, corresponde a manifestar o que antes fora ocultado ou escondido: "Pedro Mártir no utiliza este verbo, pues el vocablo presupone que estas tierras halladas allende el océano habrían sido conocidas en algún momento de la historia y que, intencionalmente, esa información habría sido ocultada" ${ }^{47}$

No lugar de falar em descobrimento (como em algumas traduções espanholas), o cronista se valeu de quatro vocábulos: panderentur (abrir, desdobrar, desenrolar, esclarecer, ou ainda, entender), repertis (dado a conhecer, mas que tem sentido próximo a "aberto"), inventurum (encontrar) e patefecit (revelou ou avistou). Ou seja, para o lombardo o feito de Colombo era algo novo, inédito. Assim, ele deveria ser narrado e divulgado, comentado e pensado, comemorado e celebrado, ainda que não tivesse ocorrido às margens da lógica do Orbis terrarum, uma terra única e revelada por Deus nas Escrituras. Tratava-se, pois, de uma novidade para a Europa, mas que já estava de alguma forma prevista, prefigurada, desde a Criação. ${ }^{48}$

\section{Narrando com o tempo: a interpretação de Antonio de Herrera}

Valendo-se de uma memória forjada nos corredores da corte castelhana do final do século XVI e início do XVII, uma parte da historiografia consagrou a interpretação de que Felipe II (1527-1598) foi o "rei do papel". ${ }^{49}$ Antes dele nunca se gastara tanto papel. O próprio monarca, diferentemente de seu pai, Carlos V, que não havia se habituado a manter pena e tinteiro próximos,

en los anales; pero lo diré con permiso de los antepasados, cuanto desde el principio del mundo se ha hecho y escrito es poca cosa, a mi ver, si lo comparamos con estos nuevos territorios, estos nuevos mares, esas diversas naciones, y lenguas, esas minas, esos viveros de perlas (...) Ven, pues; iven Rey a quien Dios tiene destinado el más alto poderío que jamás oyeron los hombres; ven y no tardes! Preparado tenemos para tí, exceptuando algo, el círculo equinoccial desconocido hasta estos tiempos, y la zona hirviente y, en opinión de los antiguos, tostada por los ardores del sol, pobladísima de gente, amena, fértil, riquísima, e islas mil coronadas de oro y perlas, y en uno sólo que reputamos continente ofrecerte hemos tres Europas. Ven a abrazar un nuevo mundo (...) de aquí, tierno y preclarísimo Rey, se sacarán medios para que te obedezca a tí todo el orbe". ANGLERÍA, Pedro Mártir de. Décadas del nuevo mundo. Madri: Polifemo, 1989, p.6.

47 CASTILLA, Carlos Enrique. Encontrar o descubrir, p.103

48 A conclusão de Castilla, no entanto, é diversa da nossa. O linguista considera que, ao não utilizar descooperire, Anglería enquadra a ação de Colombo em uma longa lista de explorações realizadas desde tempos remotos. Logo, de maneira nenhuma como um acontecimento extraordinário. CASTILLA, Carlos Enrique. Encontrar o descubrir, p.103-104.

49 ELLIOTT, John. España y su Mundo (1500-1700). Madrid: Taurus, 2007, p.36; KAMEN, Henry. Filipe II, Rei de Espanha. Rio de Janeiro: Record, 2003, p.311. 
costumava passar horas em meio a documentos e correspondências - desejoso de controlar de perto as desventuras de seus homens pelo mundo. Rei do papel, Rei Prudente. As alcunhas são às vezes eloquentes: das notícias colhidas nas leituras diárias de cartas remetidas de diferentes continentes e vice-reinos, Felipe II tirava conclusões e expedia normas..$^{50}$

Desse afã por informações nasceu o cargo ocupado por Antonio de Herrera y Tordesillas entre 1596 e 1625: Cronista Mayor de Indias. Criado em 1571, e subordinado diretamente ao Conselho de Indias, o Cronista Mayor tornava-se o responsável pela história das Índias, das descobertas à cristianização. Claro, uma história das Índias oficial, que suplantasse os relatos difusos vazados pelas penas de religiosos que nem sempre escreviam em consonância com as expectativas da Coroa. ${ }^{51}$ Herrera foi o quarto letrado a ocupar aquele cargo, e considerado um dos mais importantes em razão justamente do tempo em que exerceu a função e das obras produzidas durante esse período. ${ }^{52}$

Antes disso, em 1570, aos vinte e um anos, ele viajara à Itália a serviço de Vespasiano Gonzaga, vice-rei de Navarra a partir de 1575, com quem manteve contato próximo, o que the franqueou a circulação na corte espanhola após o fim do período italiano. ${ }^{53}$ Os cinco anos em que morou na Itália permitiram a Herrera aprimorar os estudos de gramática latina e do vernáculo, aspecto que marcou sua vida intelectual. Leitor e estudioso sistemático da tradição latina, como se percebe em seus Discursos, ${ }^{54}$ ele foi ainda o tradutor das obras de Tácito para o castelhano, além de verter para seu idioma, em 1593, um dos clássicos da teoria política do século XVI: Diez libros de la Razón de Estado do italiano Giovanni Botero (15441617), publicado pela primeira vez em 1589. Da experiência no trato com os autores clássicos, Tito Lívio e Tácito principalmente, Herrera incorporou a premissa de que a escrita e a história ensinam. Tão logo foi nomeado Cronista Mayor, em 1596, Herrera começou a escrever suas Décadas, cuja primeira parte foi editada em Madri em 1601 - edição que aqui usamos. Em 1615, ele publicou a segunda parte da obra, que como um todo tem

50 "Ha sido subrayado con insistencia el particular interés que los reyes pusieron en hacer la descripción de las Indias y la relación de cuanto en ellas sucediera; no podía ser de otra manera si querían saber cómo legislaban, sobre quienes gobernaban y de qué manera hacerlo. Las Ordenanzas de 1571 (24 de septiembre), precedente de las de 1573 expresaban claramente el interés que aquel conocimiento tenía para la Corona; conocer para gobernar: recibir la descripción de todo lo relativo a las Indias y sus mares, de su naturaleza y usos de sus pobladores así como de los asuntos temporales, eclesiásticos y seglares, pasados y presentes. En el mes de octubre de 1571 se expedía el cargo de 'cronista y cosmógrafo mayor de los estados y reinos de las Indias, islas y tierra firme del mar océano'". CUESTA DOMINGO, Mariano. De López de Velasco a Céspedes del Castillo. Revista Complutense de Historia de América, v.33, p. 15-150, 2007.

51 BAUDOT, Georges. Utopía e historia en México: los primeros cronistas de la civilización mexicana (1520-1569). Madrid: Espasa-Calpe, 1983, p.471-502.

52 CUESTA DOMINGO, Mariano. De López de Velasco a Céspedes del Castillo, p.119-121.

53 MALAVIALLE, Renaud. Temps, récit et vérité historique chez Antonio de Herrera y Tordesillas. Cahiers de Narratologie, n.15, p.1-16, 2008.

54 HERRERA, Antonio de. Discursos morales, políticos e históricos. 
oito décadas abordando os hechos castellanos entre os anos de 1492 e 1554, para a "maior glória da Coroa", pressuposto do cargo que ocupava.

Entre a crônica de Herrera e a de Anglería há, portanto, o século XVI e toda a bagagem que tal lapso temporal implica: dos vários relatos produzidos sobre a América nesse período ao do cargo de cronista maior. ${ }^{55} \mathrm{~A}$ rigor, os dois cronistas relataram em suas primeiras décadas os mesmos eventos, as viagens de Colombo e a descoberta do Novo Mundo. Contudo, diferentemente de Anglería, Antonio de Herrera narrou com o tempo, valendo-se dele, consciente de sua dimensão. Seu texto, à semelhança daquilo que se acreditava ser o bom ofício do historiador-cronista-maior, absorveu, acumulou e recortou informações fornecidas por outros autores - utilizadas conforme a autoridade de cada fonte - que pudessem servir de biruta para seus contemporâneos. As crônicas anteriores informam, pois, seu relato: ele incorporou dados encontrados nos arquivos e nos relatos de cerca de quarenta cronistas. ${ }^{56}$

Nesse sentido, Herrera não produziu interpretações sobre a descoberta da América muito diferentes daquelas conhecidas desde Anglería e difundidas durante o século XVI. Nos dois primeiros capítulos das Décadas, estabelece-se uma premissa sobre as viagens de Colombo e sua relação com a sabedoria dos Antigos: embora alguns autores, como Sêneca, são Gregório ou mesmo os mercadores cartagineses tivessem sugerido que "vendria tiempo, en que el Oceano se dexase nauegar", ${ }^{77}$ ninguém antes de Colombo tinha sabido da América. O navegador genovês intuiu hipoteticamente ("era gran Cofmografo, y tenia gran efperiencia de la nauegación") ${ }^{58}$ a existência do continente e, a serviço dos castelhanos, se lançou ao mar. As ilhas e a terra firme encontradas constituíam a grande novidade da qual Colombo teve consciência, ainda que tardia e embora lhe tenham tentado roubar a honra do feito, transferindo-a a Américo Vespúcio. ${ }^{59}$ Segundo Herrera, o Almirante se enganou, achando que tinha aportado na Ásia durante três das quatro viagens. Na última, porém, ele tomou consciência da nova terra após as notícias recebidas sobre o Oceano Pacífico (Mar do Sul). ${ }^{60}$

55 Para uma boa análise da estrutura da obra de Herrera, ver os trabalhos de Mariano Cuesta Domingo, especialmente aquele a que estamos nos referindo neste artigo.

56 CUESTA DOMINGO, Mariano. De López de Velasco a Céspedes del Castillo, p.127-128.

57 HERRERA, Antonio de. Historia General de los hechos de los Castellanos en las Islas i Tierra Firme del Mar Oceano escrita por Antonio de Herrera coronista mayor de Sv Md. de las Indias y sv coronista de Castilla: en cuatro decadas desde el Ano de 1492 hasta el de 1531. Decada Primera. Madrid: Imprenta Real, 1601, p.1.

58 HERRERA, Antonio de. Historia General de los hechos de los Castellanos en las Islas i Tierra Firme del Mar Oceano, p.3.

59 Para o "engano de Américo Vespúcio", o Cronista Mayor dedicou o Capítulo IV, do Livro IV da Primeira Década. HERRERA, Antonio de. Historia General de los hechos de los Castellanos en las Islas i Tierra Firme del Mar Oceano, p.130 e ss.

60 Antes de lançar "A invenção da América", editado pela primeira vez em 1958, Edmundo O'Gorman publicou um estudo sobre La idea del descubrimiento, no qual analisou detidamente o lugar ocupado por Antonio de Herrera na criação da ideia de descobrimento, criticada em seu livro posterior. Para esse historiador mexicano, Herrera deixou implícita uma contradição que permitiu aos historiadores modernos desconfiar do "descobrimento". Antes de Herrera, os cronistas haviam trabalhado para ocultar o suposto "objetivo asiático" das viagens de Colombo. 
O argumento parece estranho a nossa percepção, mas decerto não soava assim a Herrera e seus contemporâneos: ninguém nunca soube nada acerca do novo continente, mas Colombo havia intuído sua existência com base em "sinais e indícios", muitos dos quais extraídos dos autores antigos. ${ }^{61}$ À intuição hipotética de Colombo acrescenta-se a Providência divina, que o escolheu - a ele e aos castelhanos! -, o que explicava o fato de nenhum autor ou navegador ter imaginado ou realizado tal façanha. Sabemos, lendo O'Gorman, que a inserção da Providência divina na argumentação deve-se à apropriação e adaptação feitas por Herrera dos relatos do dominicano Bartolomé de Las Casas. ${ }^{62}$ Desse modo, Herrera aproximava-se e distanciava-se, estratégica e simultaneamente, da autoridade dos Antigos, sem contudo negá-la por completo, para afirmar a novidade americana por meio da história de Colombo. O Cronista Mayor colocava-se, para sublinhar o que afirmamos anteriormente, entre as posições antagônicas que trataram do impacto que teve a emergência da América na consciência europeia. Um fragmento extraído das Décadas sobre a questão das Antípodas talvez clareie esta afirmação:

Y aunque huuo antiguos que confeffaron que auia Antipodas, como no tuvieron la luz que dio Dios a don Chriftobal Colon, y a los Caftellanos que profiguieron tan grande emprefa, negaron el paffo de nueftro Orbe al de los Antipodas, por eftar en medio a la Torrida Zona, y el Oceano (como fe ha tocado) que los efpantaua. ${ }^{63}$

A mesma situação evidencia-se na justificativa encontrada por Herrera para o fato de Colombo ter insistido em nomear as novas terras de "Índias". ${ }^{64}$ Segundo o cronista, o Almirante quis "poner mas codicia a los Principes con quien trataua, y autorizar mas fu negociacion con efte nombre". ${ }^{65}$ Logo, não se tratava de engano, mas de estratégia.

Essa postura conciliadora de pontos de vista só é possível porque ele narrava com o tempo e com as fontes todas à disposição, observando os eventos relatados em retrospectiva e selecionando o que extrairia de cada relato. Mais de uma vez, Herrera abandonou o estilo do cronista (que pri-

O Cronista Mayor foi o primeiro a admitir, pelo menos tacitamente, tal objetivo ao expor o engano de Colombo durante as três primeiras chegadas às ilhas. Na quarta, e portanto durante o processo, ele descobriu aquilo que havia intuído. Para uma exposição detalhada, ver: O'GORMAN, Edmundo. La idea del descubrimiento de América: historia de esa interpretación y crítica de sus fundamentos. México: Ediciones del IV Centenario de Universidad de México, 1951.

61 HERRERA, Antonio de. Historia General de los hechos hechos de los Castellanos en las Islas i Tierra Firme del Mar Oceano, p.1-10.

62 O'GORMAN, Edmundo. A invenção da América, p.42-43

63 HERRERA, Antonio de. Historia General de los hechos hechos de los Castellanos en las Islas i Tierra Firme del Mar Oceano, p.7.

64 Caso se queira observar a apreciação de Herrera sobre Ofir, tema recorrente entre cronistas dos séculos XV ao XVII que se puseram a explicar o surgimento da América, ver as páginas 2 e 3 do primeiro capítulo da obra, onde Herrera lembra que "Ios mas ciertos autores afirman que Ofir es en la India Oriental".

65 HERRERA, Antonio de. Historia General de los hechos hechos de los Castellanos en las Islas i Tierra Firme del Mar Oceano, p.13. 
vilegiava o relato cronológico, como se estivesse junto dos navegadores, registrando seu cotidiano) em favor de uma "atitude historiadora", isto é, consciente do tempo que o separava dos fatos narrados e, por conseguinte, da possibilidade de interpretá-los valendo-se de sua posição onisciente. Ao descrever um animal encontrado, o cronista relatou o seguinte:

Y junto a vna vieron vn animal q les parecio lagarto de fiete pies de largo, y porque le tiraron piedras fe metio en el agua, adode le mataro co las lanças, marauillados de fu grandeza, y efpantofa figura, aunque defpues moftro el tiempo, que efta fierpe, quitado el pellejo y las efcamas, es comida guftofa. ${ }^{66}$

O tempo e o conhecimento dos desdobramentos daquele achado marcam o relato que não é mais o do cronista, que acompanha os conquistadores e detalha seu cotidiano. O cronista que porventura tivesse presenciado a cena não teria como saber que, com o tempo, aquele animal maravilhoso seria uma iguaria apreciada. Esta é a postura historiadora de quem narra valendo-se da distancia temporal, e que convive com o "estilo cronista" nas páginas das Décadas.

Dessas observações, constata-se que, além da admissão implícita do "engano parcial" de Cristóvão Colombo durante as três primeiras viagens, Antonio de Herrera não alterou substancialmente a percepção de Anglería, formulada um século antes, sobre a novidade da América. O feito do Almirante constituía algo novo, mas possível apenas em razão da luz com a qual Deus Ihe havia agraciado - e da qual os Antigos foram privados. Dito isso, convém então perguntar: se Herrera não acrescentou nada, nenhuma interpretação substancialmente diferente do que já se tinha dito, qual seria, pois, a especificidade de suas Décadas?

Na esteira de Edmundo O'Gorman, ${ }^{67}$ cuja leitura colocou Herrera como precursor da historiografia moderna sobre os descobrimentos, argumentamos que a especificidade do Cronista Mayor esteve na percepção do tempo que fundamenta sua narrativa. Para Herrera, era bastante caro o princípio da história e da retórica latinas, recuperado pelos humanistas italianos, dos quais era leitor, de que as letras e a história ensinam. Por isso era tarefa premente contar e recontar sempre o que ocorrera, para que seus contemporâneos tivessem a oportunidade de conhecer os eventos e homens do passado, e com eles aprender.

Há nas narrativas de Herrera uma estreita relação entre experiência e prudência. Não se tratava, porém, no caso das Décadas, da experiência como vivência da realidade contada, ancorada no "eu vi". A experiência era outra: aquela entendida como vivência construída e reproduzida re-

66 HERRERA, Antonio de. Historia General de los hechos hechos de los Castellanos en las Islas i Tierra Firme del Mar Oceano, p.29, grifos nossos.

67 O'GORMAN, Edmundo. La idea del descubrimiento de América. 
toricamente na crônica, distante temporal e espacialmente dos eventos, elaborada desde um gabinete ou biblioteca palaciana. Por isso, já sugerimos, o modelo encontrado em Tito Lívio Ihe foi útil. A narrativa do passado permitia reproduzir infinitamente experiências a fim de fornecer lições que pudessem orientar a ação política no presente. A história, e neste caso a de Colombo, situava-se entre a experiência e a prudência, ligando os três tempos em uma perspectiva cíclica: historia magistra vitae.

A fórmula era conhecida: busca-se o conhecimento da história para agir prudentemente no presente a fim de evitar problemas. Para Antonio de Herrera, e esta é a dimensão política de sua escrita da descoberta da América, Cristóvão Colombo era um modelo de príncipe cristão dos e para os castelhanos: parcimonioso, justo, distante o suficiente da imagem dos conquistadores que servira de fundamento à Leyenda Negra, especialmente depois dos relatos de Bartolomé de Las Casas e das imagens de Theodore De Bry (1528-1598). A distinção é necessária: Colombo representava os castelhanos, e não todos os reinos espanhóis. Do título ampliado da obra (Historia General de los hechos de los Castellanos...) ao conteúdo dos livros da primeira década, não faltaram destaques à "nação castelhana" ou "língua castelhana" ou à excepcionalidade de Castela. ${ }^{68} \mathrm{~A}$ escolha se justificava, afinal de contas Madri se consolidava na virada do século XVI como o centro do poder político da Monarquia Espanhola, e não faltavam disputas em torno de tal lugar. ${ }^{69}$

\section{Considerações finais: tempo e sentido histórico em Anglería e Herrera}

Em ambos os autores aqui analisados, a concepção de tempo estava atravessada por um sentido da história. Anglería não se considerava, propriamente, um historiador, embora soubesse estar escrevendo história para o reino mais potente de sua época, capaz de manter um espírito cruzadista e de singrar mares nunca navegados. Nesse sentido, sua concepção de história tinha função política: recordar para que não se esqueça do ineditismo e da importância daquilo que se narra. A recordação era feita através do

68 Caso emblemático da preponderância de Castela na narrativa de Herrera é a explicação dos critérios que presidiram a nomeação das ilhas encontradas. Ver: HERRERA, Antonio de. Historia General de los hechos hechos de los Castellanos en las Islas i Tierra Firme del Mar Oceano, p.33.

69 "Desta perspectiva, pode-se compreender melhor as constantes críticas feitas aos castelhanos, pelos habitantes de outras regiões da península, acusados de pretenderem se transformar no centro efetivo de dominação da Monarquia. As denúncias de uma excessiva identificação de Felipe II, e de seu governo, com Castela partiam de uma insatisfação com uma ordem política que, apesar de integrar todos seus elementos de maneira harmônica no plano simbólico, na prática, em boa medida, significava a subordinação aos interesses da coroa dos Habsburgos. A tensão entre Castela e as demais territorialidades peninsulares durante o século XVII, atingindo seu ápice na época de Felipe IV e do projeto do Conde Duque de Olivares, demonstram a disputa, ainda em voga, por o quê seria a Espanha e o quê significaria identificar-se enquanto espanhol". SAINT WILLIAMS, Rachel. A Espanha imaginada: o discurso histórico seiscentista e o projeto de uma identidade coletiva espanhola. Revista de Teoria da História, Goiânia, ano 3, n.7, p.41-65, 2012. 
recolhimento e da organização do que nunca fora visto. Tal ação era, pois, seguida de um arranjo do discurso, buscando separar a fábula da história: "De his fatis quû fabulosa mihi videantur, ad historiã à qua digressi sumus reuertamus", afirmou várias vezes ao narrar coisas que não Ihe seriam reais (como o paraíso terrenal se localizar onde Colombo parecia afirmar que estavam).$^{70}$

Esse processo de ordenação discursiva era capaz de corrigir, via uso da razão, aquilo que os sentidos da experiência, da vivência vivida, podiam obliterar ou enganar. Logo, assim como o faria Herrera quase um século depois, ponderar-se-ia entre a experiência tomada por vivência vivida, como base para as boas escolhas da história a ser narrada, e a experiência tomada por vivência construída e reproduzida retoricamente. No caso de Anglería, optou-se pelo equilíbrio entre as duas formas de pensar a experiência, um sentido de prudência muito atinado a sua concepção providencial do que seria o bom governo e a política praticada na Espanha da época.

Anglería tinha, portanto, plena consciência de seu trabalho como artífice do texto e de sua função como narrador, mas não se julgava um historiador ipsis litteris, e sim, como notamos, uma espécie de compilador, alguém que deveria dar sentido ao que the era contado ou dado a saber. Mas sabia que a fórmula das cartas que utilizava em suas Décadas era incipiente como história, afirmando-o em diversos trechos (especialmente naqueles escritos depois de 1510). Talvez por isso tenha dito que gostaria de invocar o espírito de Tito Lívio para ponderar melhor sobre o que escrevia. Ainda assim, o interesse pelo "Novo Globo" o fazia afirmar que "despertou do sono" em que se encontrava sobre o assunto e que, até cerca de 1500, pautava suas maiores afeições em temas como a questão dos infiéis, da guerra contra os mouros, da fragmentação política da Itália e do consequente derramamento de sangue que ali havia.

Fora o sentido providencial, princípio insondável que regia os destinos humanos, que o guiara para, em lugar de historiadores espanhóis, assumir a tarefar de narrar no tempo a história da Espanha e de seus feitos oceânicos. Fora também a Providência que levara a Espanha a descobrir novos mares e terras. ${ }^{71}$ Nesse sentido, estamos muito próximos de certa dubiedade que

70 "Diante desses fatos/predições que me parecem fabulosos/fantasiosos, voltemo-nos à História da qual nos afastamos"; ANGLERÍA, Pedro Mártir de. De orbe nouo Petri Martyris ab Angleria, f.XV.

71 "Servavit diuina providentia ex quo fabricare uniuersum cõstituit, immêsae uastitatis occidêtalis Oceani agnitionê ad nostra usq; tempora, in quibus tibi, potentissime Rex, maternorum auorû foelicibus auspicvjs patefacta esl. Eadem, nescio quo urgête fato, ex natali patria Mediolano, mox ex urbe Roma, ubi ferè decênium egeram, ad Hispaniam me uidetur impuliße, ut haecego miranda nouaq; particulatim colligerem, quae forte aliâs î uoraces obliuionis fauces demersa latuißent, historicis Hispanis egregvjs quippe uiris de generalibus tantum harum rerum inuentis curam habentibus". ANGLERÍA, Pedro Mártir de. De orbe nouo Petri Martyris ab Angleria, f.V. Na tradução de 1892: "Desde que la Providencia divina quiso o criar el universo, reservó el que fuera conocida la inmensa extensión del mar occidental hasta estos nuestros tiempos en que ha sido descubierta para ti, Rey poderosísimo, bajo los felices auspicios de tus abuelos maternos. La misma providencia parece que me hizo venir a España, no sé en virtud de qué destino, de mi patria, Milán, y luego de Roma donde había pasado casi diez años, para que recogiera con particular diligencia estos acontecimientos maravillosos y nunca vistos, que de contrario habrían 
pareceu caracterizar o pensamento de muitos homens do século XV, em especial a sorte de eruditos italianos à qual Anglería pertencia: a de que a História devia muito à Antiguidade, mas que os tempos modernos deveriam superá-la, sem, contudo, abandoná-la. ${ }^{72}$ Ou seja, a história pressupunha uma circularidade que em algum momento deveria ser rompida para que se caminhasse do menos, do antes, sem dele prescindir (mesmo que fosse para medir o quanto estavam corretos) para o mais, o depois. Combinamse, dessa forma, Cícero e Agostinho, fazendo variar a metáfora geométrica para a história entre o círculo e a linha. ${ }^{73}$

Com as Décadas de Herrera o raciocínio é semelhante quanto ao balanço entre Antigos e Modernos. Se o cronista narrava com o tempo - que, várias vezes, em seu relato, era um tempo cíclico -, os Antigos simplesmente não poderiam desparecer de seu relato, embora seu esforço se direcionasse para a afirmação da novidade. No entanto, tal como acreditava Anglería, Herrera também pensava vislumbrar o pináculo da história, a superação do que se tinha feito e concebido anteriormente, ao contar, no início do século XVII, a trajetória colombina. Mas, seja no formato de seu texto, as Décadas, seja no tributo pago às hipóteses formuladas na Antiguidade, da Medeia aos cartagineses, os Antigos retornam, a exemplo daquelas lembranças indesejáveis com as quais somos obrigados a conviver. Para Antonio de Herrera, a razão cosmográfica de Colombo havia superado tudo isso, a herança legada pelo passado, ao rasgar o oceano e ampliar os espaços conhecidos após intuir hipoteticamente a existência do Novo Mundo. No entanto, veritas filias temporis: a máxima bastante comum entre os escritores do século XVI assegurava que a verdade era filha do tempo. ${ }^{74}$

quedado tal vez ignorados en las voraces fauces del olvido, por atender sólo en general a estos descubrimientos los historiadores españoles, muy distinguidos por cierto". ANGLERÍA, Pedro Mártir de. Décadas del nuevo mundo, p.6.

72 CAVALCANTE, Berenice. Antigos e modernos: histórias de uma tradição. In: CAVALCANTE, Berenice (org.) Modernas tradições: percursos da cultura ocidental (séculos XV-XVII). Rio de Janeiro: Access, 2002, p.8-15.

73 A esse respeito, ver: BIGNOTTO, Newton. O círculo e a linha. In: NOVAES, Adauto (org.). Tempo e história. São Paulo: Companhia das Letras, 1992, p.176-189; DOMINGUES, Ivan. O fio e a trama: reflexões sobre o tempo e a história. Belo Horizonte/São Paulo: Ed. UFMG/lluminuras, 1996; LE GOFF, Jacques. História e memória. Campinas: Ed. Unicamp, 2003.

74 WHITROW, G. J. O Tempo na História: concepções de tempo da pré-história aos nossos dias. Rio de Janeiro: Jorge Zahar Editor, 1993, p.154. 